Research Article

\title{
Acculturation of Language and Culture among Native and Non Native Speakers of Togean in Togean Island Tojo Una Una Central Sulawesi Indonesia
}

\author{
Prof. Dr. Hasanuddin, M.Hum ${ }^{1}$, Prof. Dr. Moon Hidayati Otoluwa, M.Hum ${ }^{2}$ \\ ${ }^{1,2}$ State University of Gorontalo
}

\begin{abstract}
The objectives of the research are (1) to find out the way of the two societies with different language and culture background assimilate together in the Togean Island, (2) to find out how to adapt their language and culture among Togean Society and the tourists in Togean island, (3) to find out the tolerance attitude exist among native people and the tourist in Togean Island, and (4) to find out the sympathy attitude between two groups with different language and culture background occur in Togean Island. The research used qualitative approach. The research findings were (1) Different language and culture background assimilation occurred when NS used a foreign language (English) to assimilate their language with NNS interaction. NS developed their language assimilation by using code switching and code mixing strategies. On the other hand, NNS also tried to acquire NS language; (2) Culture assimilation occurred in both NS and NNS when they were doing cultural practice, cultural activities, food selection, and interpersonal contact in both NS and NNS of Togean. (3) Language and culture adaptation of NS and NNS occurred at (a) intensive interaction with NS and NNS, (b) followed traditional habits of the NS, (c) eat rice for meals, (d) eat traditional foods, (e) participated in social activities, and (f) attending traditional activities. (4) Tolerance attitude between NS and NNS of Togean related to respects ethnics, ideology, accepted to other people, helpful, give appreciation, and permit among NS and NNS of Togean Islands. They have good tolerance attitude each other.Sympathy attitude is important unsure that should be done in interaction for make interaction running well, particularly for native speaker and non native speaker. In this research setting founded there are a lot of aspects that getting sympathy from native speaker and non native speaker. The aspect are language used, participated in traditional festival/ceremony, wear polite dress, followed the rule that made by native speaker, and many others. The significance of this research are:This research gives a good contribution for linguistic, especially the theory of antropolinguistics, sosiolinguistics, and psycholinguistics. It can be increased various theory of acculturation in language and culture in Indonesia. The research findings are significance for developing applied linguistics for teaching cross cultural understanding. It is also significance to give information for students and teacher in promoting their learning and teaching related to language and culture, tourism sectors in Togean Island.
\end{abstract}

Key Words: acculturation, assimilation, adaptation, language, culture

\section{A. INTRODUCTION}

\section{Basic Consideration}

When we talk about language, it cannot be separated with culture. According to Gordon, culture encompasses all aspects of the way of life associated with a group of people. Similar to language, culture also is characteristic of a country. Every country has different culture that is character of people which stay or live in certain country. Culture is social category, which is it understood as all life way that own by a group of society (Jenks, 2013 p.11). It cause every group of a society have their own culture.

Language and culture are characteristics of every people, society, and country. They can be identity of every country or a group of people, and also person. There are too many different opinions about the position of language and culture. There are some scientists that said that language is a part of culture. There are also others said that language and culture are different. According to Nababan, all of communication system that used by people, include language are belonging to culture. Not different withKoentjaraningrat opinion about language and culture. According to him, relation between language and culture is subordinate relation, where language is under culture scope. It means that one of part from culture is language.

In the other side, there is other opinion about language and culture position. It comes from Masinambouw. He stated that language and culture are two systems that adhere to human. If the culture is system which organize human interaction in the society, then language is a system that has a function as tool in ongoing interaction process. Although there are two opinions about them, basically language and culture are two things that can be separated. It because of when we talking about language in our life, automatically we also will talk about culture itself. In the other word, when we talk about human 
Prof. Dr. Hasanuddin et al / Acculturation of Language and Culture among Native and Non Native Speakers of Togean in Togean Island Tojo Una Una Central Sulawesi Indonesia

life in society, we will presence with language and culture. What kind of language that they use? How about their way of speaking? How about their food? How about their clothes? When there are questions like that. So, it will talk about language and culture.

It is similar with our country. Indonesia consists of several province and island. Every province and island has their language and culture that different with other. But rights now, the language and culture not only know in that place, but also people that come from different place which have different language and culture background. It because there are too many other people that come and stay to one place that they never visit before. The people can be domestic people and also the foreign people or tourist.

The situation like that can make several possibilities which happen in the society. It possible happen adaptation, acculturation, and also assimilation between two groups of people which have different geography and social background. When the tourists visit to their new places just for a short time, it possible they will do adaptation to the language and culture of the native society. Adaptation is adjustment process of person toward his/her new society.

Furthermore, if they stay for a long time, it is possible acculturation and assimilation was happened. Acculturation and assimilation are two concepts that have different understanding. Acculturation is the acceptance of foreign culture in their culture without losing their native culture. According to Koentjaraningrat (2009. P.202), acculturation or culture contact, has some meaning from anthropologists, but all of them agree that its concept about social process that emerge if one group of people with their culture face on unsure of foreign culture, so that unsure of foreign culture will received and proceed in their native culture without delete personality of that culture. Whereas, assimilation is interference process of culture from minorities group to majorities group which can cause the minorities group lose their native culture. Koentjaraningrat stated "usually, a group of people which stumble in assimilation process are majorities group and minorities group. In here, minority group change their basic characteristic from their culture unsure and adapt to majorities culture. Then, slowdown the minority group will losing their culture and enters to majority culture". So, basically acculturation and assimilation are two concepts about the two cultures in two groups of society.

Nowadays, adaptation, acculturation, and assimilation are happening in our country. It because there are too many tourists that come from other country comes to Indonesia. They come just for spent their holiday, make business, and also not few from them married with the native people. This marital statuscauses assimilation process. Related with that statement above, Widarti have conducted research about the assimilation process at October $5^{\text {th }}$ 2012. In her research, Widarti(2012, p. 43) explained that marital status is one factor that can assimilate occurs in society. From her research with the title "Asimilasisocialbudayakomunitasketurunanarab di
kelurahanCondetBalekambang, Jakarta Timur", she found that the assimilation in society happens because of marital factor, which is the marriage between Arabian and native people. Beside that, there is other researcher that has conducted research about assimilation. Noor Aina Dani by her research with the title "Assimilation of various malay words owned by dusun ethnic in Sabah", research about assimilation between malay language and ethnic dusun Sabah language. Dani (2011, p. 86) said that assimilation between malay language and ethnic dusun Sabah language cause the emergence of new language that different with both of that language.

In this era, assimilation among two groups from different country often happens in almost province in Indonesia, such as Jakarta, Bali, Java, and also Celebes. In Celebes, especially in Central Celebes, there is a small Island that every month there is too many tourists that come to that place. It name is Togean Island. Togean Island is one Island that famous with the name hidden paradise. Although the Togean Island is not really famous like Bali, but right now there too many touristsfrom foreign countries comes to that place. The tourists come from several countries, such as England, Slovakia, Irlandia, Australia, Germany, Dutch, Italy, and others. They come to the Togean Island for spent their holidays. They stay there in various times. Several of them stay there just for three days, a week, a month, three months, seven months, and also not a few from them that stay there forever because they have married with the native people.

\section{Focus of the Research}

The study on language and culture will focus on the assimilation process of language and culture which is happen among Togean society and tourists in TogeanIsland. This is an ethnographic study, which study about culture of a society as a field work. In study about language and culture, there are several things that happen, such as adaptation, acculturation and also assimilation. According to Koentjaraningrat (2009), assimilation is social process which is happen if there are (a) human groups with different culture background, (b) intensive interaction in long time, so (c) their each culture change it feature, and their culture change become mixture culture. In this case, theparticipants are two families which the husbands are tourist, and two tourists which have boyfriend from native people. The tourists are come from different countries that have stay for a long time in TogeanIsland. Beside focus of research, w also have several sub focus on our research. They are (1) Two groups of society with different language and culture background, (2) Intensive interaction since long time between two groups with different language and culture background, (3)The emerge of new culture among two different society, (4) the tolerance attitude between two different groups (5) an attitude of sympathy among those society.

The main research question of this research is "How do the acculturation of language and culture among Non Native and Native Speakers in Togean Island?'.Besides that, there are also several research questions that become basic of researcher 
Prof. Dr. Hasanuddin et al / Acculturation of Language and Culture among Native and Non Native Speakers of Togean in Togean Island Tojo Una Una Central Sulawesi Indonesia

in doing research. They are as follow;

1. How do the two societies with different language and culture background assimilate together in the Togean Island?

2. How do among Togean society and the tourist in Togean Island adapt their language and culture?

3. How do the tolerance attitude exist among native people and the tourist in Togean Island?

4. How does the sympathy attitude between two groups with different language and culture background occur in Togean Island?

\section{The Objectives of Research}

The objectives of the research are (1) to find out the way of two societies with different language and culture background assimilate together in the Togean Island, (2) to find out how to adapt their language and culture among Togean Society and the tourists in Togean island, (3) to find out the tolerance attitude exist among native people and the tourist in Togean Island, and (4) to find out the sympathy attitude between two groups with different language and culture background occur in Togean Island.

\section{The Significance of Research}

The significance of this research are:

This research will give good contribution for linguistic, especially the theory of antropolinguistics, sosiolinguistics, and psycholinguistics. It can be increased various theory of acculturation in language and culture in Indonesia. The research findings are significance for developing applied linguistics for teaching cross cultural understanding.

It is also significance to give information for students and teacher in promoting their learninbg and teaching related to language and culture, torism sectors in Togean Island.

To give new information for the domestic and tourist about the TheTogean island in the context of acculturation in language and culture.

\section{B. THEORETICAL AND CONCEPTUAL FRAMEWORK}

\section{Theory Adaptation, Acculturation, and Assimilation}

Social interaction which happens between two groups that have different language and culture background can emerge some possibilities, such as adaptation, acculturation, and assimilation. Those concepts have different meaning and understanding. Adaptation is process of someone's adjustment toward his/her new climate or environment. The Intergovernmental Panel on Climate Change (IPCC) in UK Climate Impact Program,explained adaptation as "an adjustment in natural or human systems in response to actual or expected climatic stimuli (variability, extremes, and changes) or their effects, which moderates harm or exploits beneficial opportunities" (IPCC TAR, 2001). Other opinion about adaptation is comes from Smith and Wandel. They said that adaptation in the context of human dimensions of global change usually refers to a process, action or outcome in a system (household, community, group, sector, region, country) in order for the system to better cope with, manage or adjust to some changing condition, stress, hazard, risk or opportunity.

Additionally, O'Brien and Holland in Smith (2006, p 283) explain the process of adaptation as "one by which groups of people add new and improved methods of copying with the environment to their cultural repertoire". Besides that, anthropologist and archeologist suggest that adaptation is a consequence of selection acting on variation through cultural practice (adaptation) which has historically allowed a culture to survive (Smith \&Wandel, p 283). From several theories about the explanation adaptation concept, basically adaptation process is adjustment process of someone toward her/his new situation and place. Beside adaptation, there is also acculturation in social interaction.

Otherwise, acculturation has different understanding with adaptation. Gillin and Raimy give explanation about acculturation as the processes whereby the culture of a society is modified as a result of contact with the culture of one or more other societies. Addition explanation about concept of acculturation comes from Redfield, Linton, and Herskovist. They defined acculturation as "those phenomena which result when groups of individuals having different cultures come into continuous firsthand contact, with subsequent changes in the original culture patterns of either or both groups". In line with their opinion about concept of acculturation, Koentjaraningrat (2009) said that acculturation or culture contact, has some meaning from anthropologists, but all of them agree that its concept about social process that emerge if one group of people with their culture face on unsure of foreign culture, so that unsure of foreign culture will received and proceed in their native culture without delete personality of that culture. From several theories above I can said that acculturation is process received and proceed of other culture because of continuous contact with the other people which come from different culture background, but without losing and forget their native culture.

The other possibility that happen in social interaction between two different groups is assimilation process. Different with acculturation process, assimilation is formed process of new culture/mix culture because two groups of people which is comes from different culture background stay together in one society in long time. Berry defined "assimilation" tobe the situation where either (i) an individual turns his back on his originalcultural background and identity and chooses to identify and interact with themembers of the host society or (ii) a national society expects foreigners toadopt wholly the culture of the larger national society. Furthermore, Teske and Nelson (1974) explained that acculturation and assimilationto be two separate and distinct processes that may be differentiated on a number of dimensions. They indicate that acculturation is potentially bidirectional and reciprocal in terms of influence (i.e., the two groups in contact influence each other). Assimilation on the other hand is unidirectional in 
Prof. Dr. Hasanuddin et al / Acculturation of Language and Culture among Native and Non Native Speakers of Togean in Togean Island Tojo Una Una Central Sulawesi Indonesia

its influence (i.e., a host group unilaterally exerts some influence on another group).

According to Koentjaraningrat (2009) assimilation is social process which is happen if there are (a) human groups with different culture background, (b) intensive interaction in long time, so (c) their each culture change it feature, and their culture change become mixture culture. The other expert that gives opinion about the concept of assimilation is Milton Gordon. As stated by Gordon quoted by Pratiwi (2011, p. 7), there are seven stages in assimilation process. They are: (a) Cultural or Behavioural assimilation, (b) Structural assimilation, (c) Marital assimilation, (d) Identification assimilation, (e) Attitude receptional assimilation, (f) Behaviourreceptional assimilation, and (g) Civic assimilation

Additionally, Sutirto cited in Pratiwi (2011, p. 6) proved that interaction that happen widely and intensively not emerge the assimilation among two groups that stay together if there is not an attitude, such as, tolerance and sympathy for each other.

From explanation above, we can say that in social interaction between two groups with different language and culture background in society can cause adaptation, acculturation, and assimilation. Furthermore when that two group that have tolerance and sympathy attitude, stay together for a long time, and make intensive interaction for a long time, it can happen assimilation. Assimilation is the emergence process of new culture that happens because there are two different societies that stay together and doing interaction since long time. In the other word, assimilation has five key words. They are; (1) two groups with different language and culture background, (2) intensive interaction which happen among them, (3) the emerge of new culture in two society, (4) the tolerance attitude between two different society, and (5) the sympathy attitude among two society with different language and culture background. The explanations are:

\section{a. Different Language and Culture.}

Language and culture are two things that cannot separate each other. It because, when we talk about language, it means that we also talk about its culture.Masinambouwstated that "language and culture are two systems which close to human. If culture is system which arrange human's interaction in society, so language is a system that has a function as the interaction tool.

Every group, place and country has their own language and culture that automatically different with the others. Language and culture are characteristics of every country. So, it possible happen several possibilities when two different society or country meet in one place.

In our country, that case becomes something that familiar in societies. Many unique culture and beautiful place in our country make the visitors/tourists come to our country for visit our country. Then, almost of them decided for stay and become Indonesia citizen. They come from different country, automatically they also bring their language and culture that different with our language and culture as a native country.
These situations that can make assimilation happen in that case. It is because if they stay together in one society, automatically they will do interaction although they come from different language and culture background.

\section{b. Intensive Interaction.}

When people stay together in one place, the interaction automatically is happen. Although the people are come from different language and culture background, the social interaction is happen. Hurst (2003) defines social interaction as action with one another as a means of communication both verbally and non-verbally. Interaction can happen between two people or more when they stay together in one place. Although they come from different language and culture background, interaction also can happen. These situations that can make assimilation happen. Moreover, if intensive interaction occurs among them since a long time, it possible that the assimilation can occur.

\section{c. The emergence of new culture.}

New culture can emerge in one society if there is intensive interaction between two different language and culture background. The emergence of new culture is one of result from assimilation process. New culture that emerges from assimilation process is culture that different with two cultures that merge become one culture.

In this time, the emergence of new culture that different with the native culture in one society is usual thing. It is because, in this era there are too many people that immigrate for one place to the other place. When people come to their new environment or new places, it makes them should interact with the native society. The interaction between them can be a habitual. The native people or society that has cultural contact with the society with different cultural background can make the native people easy in receive the foreign culture. That attitude enable to emergence new culture in that society.

Furthermore, it is clear that meeting process between two groups with different language and culture background can cause the emergence of new culture. If they meet and live together in one place, automatically interaction will occur among them. Every place has one purpose. In getting that purpose, its society should have collective purpose. So, that purpose can reach by them if they lose contradiction between them. Once more, these things that can make the new culture are emerged.

\section{d. The tolerance attitude in society}

In this era, there are two and more groups of people come from different culture background stay together in one society. This case can cause assimilation. Although there are two groups with different language and culture, in fact the interaction among them are still happen. In fact, it is impossible that assimilation can happen in that society if there is no tolerance attitude among them. In the other word, every person that stays together with the others in one society should have tolerance attitude. 
Prof. Dr. Hasanuddin et al / Acculturation of Language and Culture among Native and Non Native Speakers of Togean in Togean Island Tojo Una Una Central Sulawesi Indonesia

Tolerance is one of important factor in assimilation formed. It is because if there are two groups with different culture will stay and doing interaction in one society not have tolerance to each other, so it can cause too many dispute between them. Holetzky (2003, p.1) said that tolerance means to tolerate or put up with differences. It means showing respect for the race, religion, age, gender, opinions, and ideologies of other people or groups. This concept means different things to different people, but it is when something is disagreeable that tolerance is expected, and in more politically correct cultures, demanded.

Mihulka said "in any other multiethnic country, a great deal of tolerance is required". As JolantaAmbrosewicz-Jacobs points out,"the attitude of tolerance comes from the individual rather than the state, but the community or the state is responsible for the fact of tolerance, that is, for ensuring that no one is victimized by intolerance". In addition, Jerzy Szackiin Mihulka (2008, p 2) definedtolerance as an attitude of acceptance of others who may hold and advocate different views, and also follow lifestyles one personally does not approve of. Spiewak (2000, p 530) also explain, "Positive tolerance', then, means not only an awareness of diversity, but also a positive attitude towards 'the other', an openness to 'the other' as well as willingness to respect and support diversity in others.Then, Supriatna (2000. Pg. 87) said that tolerance is appreciate, permit, and give authority about opinion, belief, view, tradition and behavior that different with theirs.

Basically, tolerance is an attitude that really important in assimilation formed. Assimilation among two different groups in one society can happen if there is tolerance attitude between them. In the other word, the native society can respect and appreciate toward foreign people that come to their society with their own language and culture.

\section{e. The sympathy attitude in society.}

Sympathy is an attitude or emotional feeling of someone toward something. Sympathy is one of important thing that can influence assimilation process. Two different language and culture cannot assimilate if there is no sympathy attitude between the users that comes from different language and culture background. Sutirto said that it is impossible the assimilation can happen among two groups with different language and culture background, if there is no tolerance and sympathy attitude among them.

It is clear that one factor that can emerge the assimilation is sympathy. Supriatna (2000) defines sympathy is complicity feeling of one group toward the other group in one society that have different language and culture background. It includes feel care and participate toward other communities' feeling, such as happy, sad, proud, and emotion. Other opinion about definition of Sympathy comes from Gillin. Gillin said that Sympathy is a process where is someone attracted with other people. Prime motivation in sympathy is pretension for understanding other person, and doing cooperation.

Furthermore, sympathy is really important in assimilation process. Two groups with different culture background that live together in one society cannot assimilate their language and culture if there is no sympathy attitude among them. It is clear that in assimilation process, sympathy attitude is really needed.

\section{Language and Culture}

Language is characteristic of people, a group of people, and also society. Language is tool that used by people for communicate to others in the society. The tool that used by people in communicate to each other can be in sound form, sign and symbol, and various form based on where place and country the language used. Schultz (2003. P.32) explained that language is a system of arbitrary vocal symbols that human being use to encode their experience of the world and to communicate with one another. It refers that language related with interaction and communication of human through sound and symbol.

In line with Schultz opinion, Gleason (1961. p.2) said “.... Language operates with two kinds of material. One of these is sound. Almost any sort of noice that the human vocal apparatus can produce is used in some way in some language. The other is ideas,social situation, meanings.....". Additionally, Chaer describes about the essence of language, according to him, the characteristic of language essence are language are system of symbol, sound, arbitrary, productive, dynamic, various, and humane. (Chaer, 2010.p.11).

Theories above explain that basically language is talking about the symbol and sound, and its meaning. In the other word, symbol and sound are two basic essences in composing the language. In linguistic study, we know with the term phonology, morphology, syntax, semantics.

\section{Previous Study and Road Map}

The followings areprevious study in the field ethnography of language and culture acculturation that is related to assimilation and adaptation. In the research that composed by Richard Alba, with the title "Language Assimilation Today; Bilingualism Persists More Than in The Past, But English Still Dominates". His research conducted at December 2004. It discussed about immigrant who have come to the U.S. in the great number. In this case, the grandchildren of immigrants, bilingualism is maintained only by minorities of almost all groups.English monolingual is the predominant pattern. So, there is maintenance of language from minority group. The assimilation of language that occurs is small. In my research, I look for the assimilation that occurs in the field of research too. But in this research, I do not look for the maintenance process, but I focus on the assimilation process of language and culture between the tourist and the native people.

The next is research that composed byNoor Aina Dani, with the title "Assimilation of various malay words owned by dusun ethnic in Sabah". It discussed about assimilation between malay language and ethnic dusun Sabah language. Where the aim of his research is focus on language assimilation between malay language and ethnic dusun Sabah 
Prof. Dr. Hasanuddin et al / Acculturation of Language and Culture among Native and Non Native Speakers of Togean in Togean Island Tojo Una Una Central Sulawesi Indonesia

language that can cause the emergence of new language that different with both of that language.Different with this research, that not only focus on language assimilation but also on culture adaptation, tolerance and sympathy attitude .

The last is the research in "AsimilasiSosial Budaya Komunit as Keturunan Arab di KelurahanCondetBalekambang, Jakarta Timur", that composed by TitinWidarti. It discussed about the assimilation that happen between Arabians and Jakarta people.
The assimilation happens because of marital factor, which is the marriage between Arabian and native people. This research similar with our research, which is talking about the assimilation between two different cultures, but her research discussed about Arabian culture and Jakarta culture. Meanwhile this research discussed about acculturation of language and culture of native and non native speakers of Togean in Togean Islands Tojo Una Una.

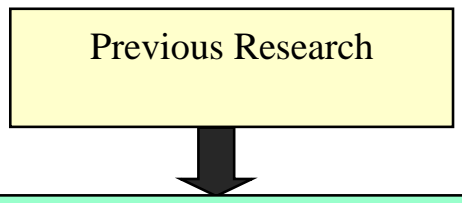

1. The influence of social networks on the acculturation behavior of foreign students (Tsungchi Kenny Hsu, Grant August E., Wei-Wei Huang, 1993)

2. The effect of acculturation on second language proficiency in a community a two-way bilingual program (Brown, C. and Graham, C.R., 1996)

3. Measurement of acculturation, scale formats, and language competence: their implication for adjustment, Sun Mee Kang, 2006)

4. Acculturation and language acquisition: a look at Schumann's acculturation model,( Chizzo, Jacob., 2002)

5. Acculturation of language and culture through manifestation of lexical usage in Cross Indonesia-Melayu (Iswary, Ery, Bin Aman, Rahim, 2011)

6. A Study on Language acculturation of Korean Descendants in Germany, (Young-Mi Choi, 2014)

First Year 2015
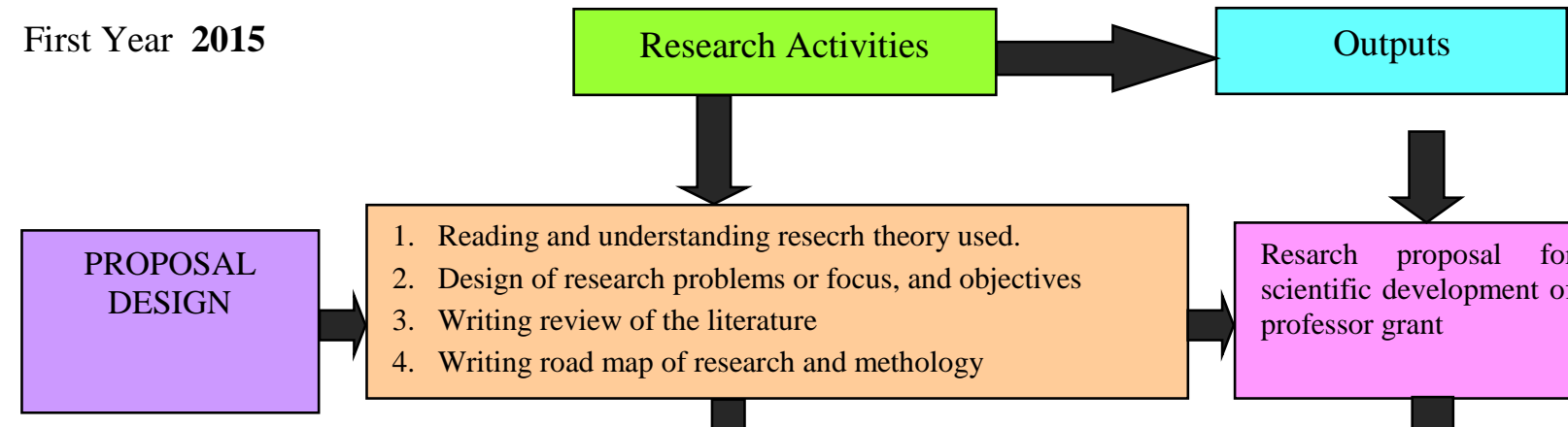

1. Reading and understanding resecrh theory used.

2. Design of research problems or focus, and objectives

3. Writing review of the literature

4. Writing road map of research and methology

DATA

COLLECTION

AND ANALYSIS

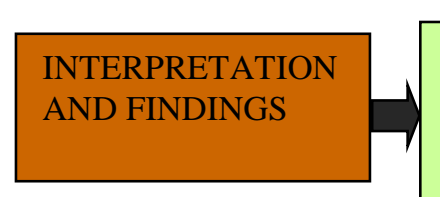

1. Data triangulation

2. Data interpretation in four research focus

3. Set up findings and conclusion

4. Writing final draft of research report
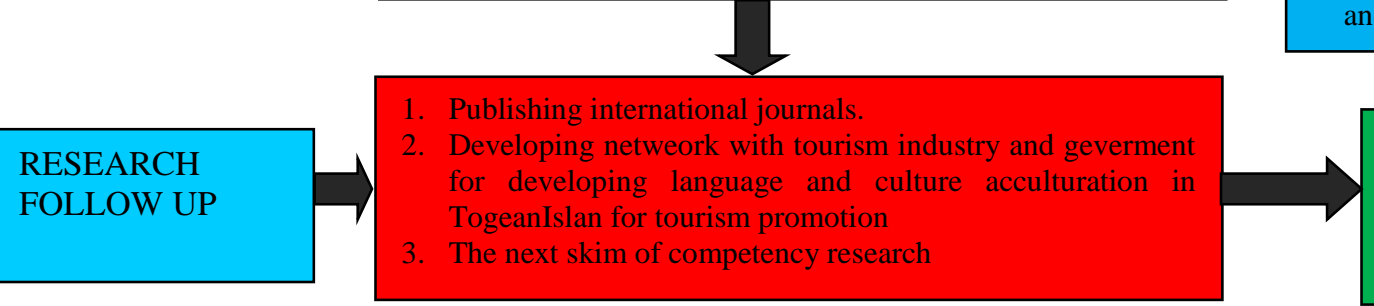

Resarch proposal for scientific development of professor grant

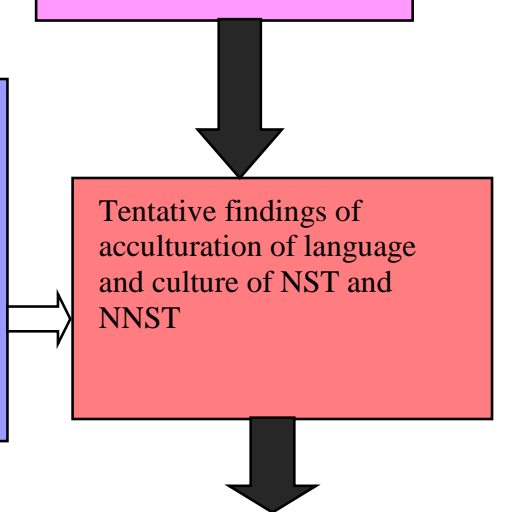

1. There is research findings and report on Acculturation of language and culture of NST and NNT in different language and culture.

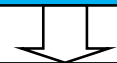

International articles

and government and

tourism industry

network area available 
Prof. Dr. Hasanuddin et al / Acculturation of Language and Culture among Native and Non Native Speakers of Togean in Togean Island Tojo Una Una Central Sulawesi Indonesia

\section{RESEARCH METHODOLOGY}

\section{Approach and Design}

In this research used qualitative method. It purposes to explain, analyze, and interpret the data, and then describe the result of the research based on the focus and sub focus of the research. Patto and Cochran (2002. p.2) said that qualitative research is characterized by its aims, which relate to understanding some aspect of social life and its method which (in general) generate words, rather than numbers, as data for analysis. It supported by Strauss and Corbin (2003, p. 4), they said that qualitative research is kinds of research that its result was found not from statistic procedure.

The approach which use in this research is ethnographic approach. According to Creswell, ethnography is a qualitative strategy in which the researcher studies an intact cultural group in a natural setting over a prolonged period of time by collecting primarily observational and interview data. It means that the researcher should stay together with the participant in a long time to get the primary data. Craib in Bungin explains that ethnographic has tried to use the competency to describe the understanding about how the social world done the activity. Ethnography is chosen because this research is aim to research about assimilation of language and culture that occur in the participant.

\section{Research Setting}

This research was conducted at Togean Islands, especially in Kadidiri Island. It located in Central Celebes District of Tojo Una-Una. Kadidiri Island is one of several Islands in Togean Island, which is until every month there are a lot of tourists that visit to that place.

The research were done at July to October 2015. We have done pre survey and pre observation to determine the Informant and subject/participant of research. The informant is different with the subject or participant of the research. Informant is partner or researcher friend that can help researcher for getting information about things in the society that become research place of the research. Spradley (2006 p.39) said "Informant is information source, or literally, informant as a teacher for the researcher. In collecting the data, I observed the subject of the research in family circle, market, and resort area.

\section{Source of the Data}

This research was conducted at Native Speakers of Togean and Non Native Speakers (foreigners) that were used as sources data. Data were collected according to the reseach focus. Data were related to assimilation, adaptation, sympathy attitude.and tolerance attitude toward Native Speakers of Togean and Non Native Speakers of Togean (Foreigners).

There were some reasons why the participants were chosen. The reasons are; first, this research is ethnography ,that exploring about the language and culture in a society in naturally; second, the participants are suitable because in a society there are lived together two different group of people, they are a native people and the tourism that have different language and culture.

\section{Technique for Collecting Data}

The technique of collecting data of this research used the collection procedure in qualitative research as in the following.

\section{Observation}

Direct observation is meant very broadly here. It differs from interviewing in that the observer does not actively query the respondent. It can include everything from field research where one lives in another context or culture for a period of time to photographs that illustrate some aspect of the phenomenon (William, 2006 p.1)

\section{Interview}

Interviews are particularly useful for getting the story behind a participant's experiences. The interviewer can pursue in-depth information around the topic. Interviews may be useful as follow-up to certain respondents to questionnaires, e.g., to further investigate their responses. (McNamara,1999).

\section{Field Notes}

In this research, I will use field notes. It purposes to make note about information which not covered in the observation checklist. It deals with the interaction that occurs between tourist and native people in the family circle, neighbor, market, and also resort area.

\section{Video Record}

There are various ways in which to conceptualize the video clip, but one useful perspective from perceptual psychology is that video segments represent events. Any video corpus captures many events. Selection determines which events are brought into focus for deeper analysis. (Zacks\&Tversky, 2001).

\section{Data Card}

Data card is one of technique that really important for the ethnographer to collecting and classifying the data. It used by researcher for help the researcher to classifying and analyzing the data. Marina (2013. p.4) said that data card used to make the researcher easy in processing the data by classify the data. The data card consists of several things that become focus and sub focus of the research. It can be consisting of the date when we collecting the data, the place where we collect the data, the focus/sub focus, and our interpretation about the data that the researcher have gotten.

\section{Technique of Analyzing the Data}

Bogdan and Biklen cited in Moelong (2004, p. 248) said that data analysis is process of organize the data, synthesis the data, find out the structure, and find out the important thing and what have learnt, and decide what data that we can tell to others.

In analyzing process, the researcher analyzed the data 
Prof. Dr. Hasanuddin et al / Acculturation of Language and Culture among Native and Non Native Speakers of Togean in Togean Island Tojo Una Una Central Sulawesi Indonesia

continuously from the beginning in doing research until finish. It based on the real fact and the natural life in the field. This data were analyzed to gain information about; (1) what data that still be looking for, (2) what theory which were found, (3) what questions which were solved and answered, (4) what should the researcher do to find out the new information, and (5) what mistake which should be corrected. When all of the data that the researchers needed have collected, the researchersanalyzed data qualitatively. The researchers used several steps in analyzing the data based on Spradley theory. The steps are:

\section{Domain analysis}

Domain analysis is the first step that researcher do in analyzing the data. Domain analysis is used by researcher for get universal description about the setting of research. There are nine types of systematic relation that can used in investigate domain ( Faisal in Bungin, 2012. p. 193);

\begin{tabular}{|c|c|c|}
\hline a. & Strict Inclusion & $\mathrm{X}$ is kind of $\mathrm{Y}$ \\
\hline b. & Spatial & $\mathrm{X}$ is place in $\mathrm{Y}$ \\
\hline & & $\mathrm{X}$ is part of $\mathrm{Y}$ \\
\hline c. & Cause-Effect & $\mathrm{X}$ is result of $\mathrm{Y}$ \\
\hline & & $\mathrm{X}$ is cause of $\mathrm{Y}$ \\
\hline d. & Rationale & $\mathrm{X}$ is reason doing $\mathrm{Y}$ \\
\hline e. & Location & $\mathrm{X}$ is place doing $\mathrm{Y}$ \\
\hline f. & Means-End & $\mathrm{X}$ is way for doing $\mathrm{Y}$ \\
\hline g. & Function & $\mathrm{X}$ is used for $\mathrm{Y}$ \\
\hline h. & Sequence & $\mathrm{X}$ is step in $\mathrm{Y}$ \\
\hline 1. & Attribution & $\mathrm{X}$ is characteristic of $\mathrm{Y}$ \\
\hline
\end{tabular}

From that semantic relation, researcher found that there are several domains in setting of research. The first is Togean Island which is including of resort area, family circle, neighborhood, and market. The second is society that consist of tourist and native people ( Togean ethnic). The next is interaction process that include of different language and different culture. Then the last is the events that happen in that place, such as marital event, special relationship, and various time in stay.

\section{RESULT AND DISCUSSION}

\section{Description of Togean Islands}

Togean Island is Islands that located in Central Celebes. It becomes one of the tourist destinations in the world. It has multilingual society. Not only various kinds of language can be found but also many various cultures integrated in this Island. The detailed of the Togean description about territorial, society, tourism, and livelihood as followed;

\section{a. The Territorial.}

Togean Island is a small Island in Celebes province, Central Celebes of Indonesia. It is located in the central of Tomini bay. In administrative, it includes in Tojo Una-Una regency area, which is located in Celebes province especially in Central Celebes, Ampana. It has length about 90kilometres. Togean Island is a part of national park which is located at coordinat line $00^{\circ} 07^{\prime} 43^{\prime \prime}-00^{\circ} 65^{\prime} 06^{\prime \prime} \mathrm{LS}$ and $121^{\circ} 51^{\prime} 63^{\prime \prime}$ $122^{\circ} 44^{\prime}$ 00" BT. In north, it is border on Tomini bay and Gorontalo province. Next, in the south, it is border on Deep Sea and mainland of Celebes Island. Then, in the west it
Tourist is one of Society in Togean Island

Resort place is

one of place in Togean Island

New culture is result of

Assimilation among tourist and native people

IntensiveInteraction is one reason the emerge of assimilation

Resort area, Market and family circle are place for doing interaction

Stay for a longtime in Togean island is one way to interact with the native people intensively

Language and culture used for doing interaction

Making good relationship and married are the steps of occurring assimilation

Tolerance and

borders between Tomini bay and Deep Sea. In the east, it is border on Moluccas Sea (source: document of Dive Center Togian Island, Wakai). Thus, it position is across from west to east. It can be showed in this map below.
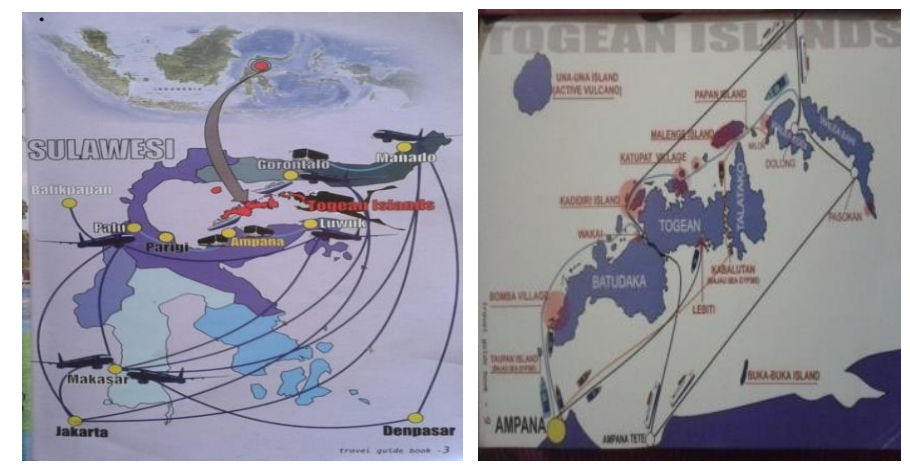

(source: Wonderful Togean, Part of Wonderful Indonesia, Dinas Kebudayaan dan Pariwisata KabupatenTojo Una-Una)

\section{Picture 1}

Map of Togean Island, Ampana, Central Celebes, Indonesia.

According to the source of Bps Kabupaten Tojo Una-Una, it found the wide of Togean Island's mainland is about $755.4 \mathrm{~km}$ or about 75.000 ha, meanwhile its waters is about 360.000 ha. It consists of 57 big and small Islands, such as Wakai, Kadidiri Island, Taupan Island, Katupat Island, Malenge Island, Papan Island, Kabalutan, and others. There are three largest islands namely Batukaa, Togian, Talatakoh. From all of Islands, there are 37 villages on the Islands. One of them is settled by sea gypsy that is Bajau people. If we will go to that Togean Island, we can use three alternative ways. The first, we can go there 
Prof. Dr. Hasanuddin et al / Acculturation of Language and Culture among Native and Non Native Speakers of Togean in Togean Island Tojo Una Una Central Sulawesi Indonesia

through Luwuk. Then we take car transportation to Ampana regency. It spent 6 hours from Luwuk to Ampana. Next, for getting the Togean Island, we can use sea transportation. It is spent time about 4 hours. The second alternative way is from Gorontalo. We use sea transportation for go to the togean Island. It spent 8 hours. The last alternative way is from Marisa. It just spent 4 hours to arrive in Togean Island by using sea transportation.

\section{b. The society.}

The society in Togean island have various of ethnic background, such as Bobongko, Bajo, Saluan, Togean, Kaili, Bare'e, Taa, Gorontalo, and Bugis. Between them, there are several ethnics that became controversy as the first ethnic in Togean Island. Based on Hasan (cited on Sundjaya, 2008. p. 43), Togean ethnic who stayed in Benteng village is the first ethnic in Togean Island. It means according to him, Togean is the native ethnic of the society. Different opinion comes from Darnaedi. He said Bobongko and Bajo are the first ethnics in Togean Island (Sundjaya, 2008. p. 42). Here, Darnaedi has opposite opinion about the first ethnic. He said Bobongko and Bajo are the first ethnic. The experts' statement above is again facing by the linguistic from Dutch, Nicolaus Adriani. Adriani from his research entitled "The Language of The Togian Island" explained that Bobongko, Saluan, and Togian ethnic have root from Limboto. Thus, according to her it was possible they are generation from Limboto people who immigrated to Togean Island in 1880. (Sundjaya, 2008. p.43)

Nevertheless, Togean ethnic is reputed in societies as the native ethnic. Almost the societies said that they are Togean ethnic. They are spread in almoat Islands. Every Island placed by society in several families. In the other word, every Island has population. One of the Island for instance, it has 5000 populations. So, the total number of the society in Togean Island is about 30.000 populations that consist of several ethnic. Almost of them are Moslem. (source: Document of Dive Center of Togean Island, Wakai).

Togean society used boat as their prime transportation tool beside bycycle, motorcycle, and cart. It is because almost the Togean Island is consisting of water. Generally, they used traditional boat (They called "Bodi") that has speed about 5,5 PK for transportatation between Islands. For instance, they used bodi from wakai to Kadidiri Island, or Katupat to Malenge, and etc. Moreover, they used public boat when the destination is far, such as Ampana-Wakai, Wakai-Gorontalo.

Furthermore, their house style also is still traditional. Although there are several society's house that have been touch modern style, but the dominant of their house style is still traditional, from example, Kabalutan Island, Malenge, and Papan Island. Papan Island is small Island in the east part of Malenge. It is an icon of Togean Island. Here, their houses were built above the water. All of their houses and building such as mosque, offices are made from wood. Moreover there is also a very long bridge that made from wood. In the other word, the building and houses in Togean Island generally are made from wood and built above the water.
The society also based on the custom. There are too many traditions and beliefs that still occurred in their daily life in among the greatest number of the foreign visitor and the new comers. For instance, the belief and custom that we can find are kampunanga, padungku, bakedang, sando, kantau and others. Kampunanga is belief of the society which is we should eat or drink the food that served by the host if we visited her/his house. We can not ask permittion for comeback if we not drink the water until finished. The other custom is padungku. Padungku is societies' ceremony. It is like the thanksgiving or harvest festival. It performed traditional dancing and singing which is preceded by a formal prayer or blessing. The next custom is bakedang. Bakedang is traditional ceremony for the young girls that get their first period. This ceremony should performances kantau. Kantau is obligated dancing that must performed in every ceremony. The other custom also that still belief in this society is sando. Sando is old grandmather that always help the pregnant woman for getting born. Several of societies were getting born by sando. There are also several societies that called sando, although there is nurse or midwife has helped them. Those habitual always occurred in the society, although there are too many foreign visitors in great number that come to that place in every day.

Togean society is multilingual society. It means they have more than one language. They are Bobongko, Bare'e, Ta', Saluan, Bajo and also Togean. Between all of them, Togean language is familiar and often used in the societies' daily conversation. In this era, the greatest number of the foreign tourist who visited Togean Island almost every day makes the society also understand about foreign language. Moreover, there are several tourists from other countries which is married with the native people, and then become Togean society. Thus, these societies not only understand about their several regional languages and national language, but also the foreign language.

\section{c. The Tourism}

Togean Island is one tourism destination in the world. This island is worth with the sea. It is famous with its beautiful sea park. Because Togean Island is very famous with its beautiful tourism, until every month there are too many visitors that come and stay to that place for several days, months, and year. The visitors are not only domestic but also foreign tourists. It calculating in December 2014, there are about 104 tourists who visited this island. In the other word there are about 719 tourists who visited Togean Island in last year (source: document of Dive Center).

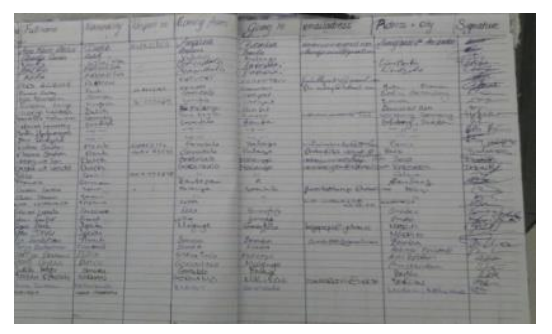

Picture 2 
Prof. Dr. Hasanuddin et al / Acculturation of Language and Culture among Native and Non Native Speakers of Togean in Togean Island Tojo Una Una Central Sulawesi Indonesia

The book list of the visitor on January, $10^{\text {th }} 2015$

Then almost of the visitors or tourist are from various countries. In the word, the tourists are foreign tourists. So, it becomes common view in Togean Island if the societies (native people) interact or communicate with the foreign people (tourist).

There are several resort places that usually become the tourists' destination, such as Kadidiri Island, Katupat Island, Bajo Island, and etc. They have their own characteristic to attract the visitors. The detailed are below;

\section{d. Kaidiri Island.}

This Island is the most beautiful Island in the Togean Island. There are three resort area built in this island namely Pondok Lestari, Black marlin, and Paradise. The steep big coral in this island become characteristic of this Island. Moreover, the beautiful reef and various kinds of fish complete the beautiful of this place. Besides that, there is also wreck of America Airplane which is crashed at sea on $3^{\text {rd }}$ May 1945. Until now, the plane is still in good condition under the sea. It becomes home from the sea animal and plants, such as beautiful fish, reef, sponge, microrganisme, and the others. (source: Dinas Kebudayaan Dan Pariwisata Kabupaten Tojo Una-Una).
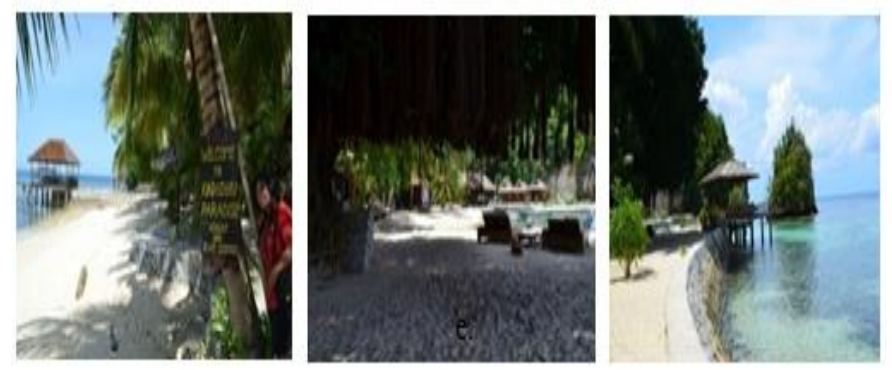

\section{Picture 3}

Kadidiri Island; Pondok Lestari, Black Marlin, and Paradise

Wakai is one of big Island that becomes a main gate for the tourists enter the Togean Island. It also can be considered as central of Togean Island. There is a Dive center that becomes place for the tourist doing registeration. All of information about the tourist destinatioan and the activity that served each resort can get in the dive center.

2. Different Language and Culture Background Assimilation

Native speakers of Togean used language of Non Native Speakers of Togean. Native Speakers of Togean used foreign language especially English. Native Speakers of Togean acquire a foreign language, for instance, English in order to interact with Non Native Speakers of Togean. Non Native Speakers of Togean were generally tourists that they spent their time for holidays and found interesting place to be stayed and enjoyed themselves. Therefore, Native speakers of Togean assimilate their language and used a foreign language in which that language is understood by tourists. Most of the time, Native speakers of Togean used a foreign language, for example, English in their communication with tourists. In this event, there is a process of assimilation between Native
Speakers of Togean and Non Native Speakers of Togean.

Native Speakers of Togean assimilate their language when they interacted with tourists. They applied code switching and code mixing strategies to avoid their communication. Code switching and code mixing were the way to develop their language assimilation.

In a short stay of NNS, NS were influenced by NNS for assimilating their language. NS used a foreign language a lot to the NNS. However, NNS also tried to learn NS language (Indonesian and local language or mother tongue). On the other side, NNS (foreigner who has already stayed in Togean for a long time acquired NS language (Indonesian and Togean Language to immert or insert themselves into NS societies.

Observation results inbdicated that language assimilation of both NS and NNS of Togean occurred when both of them (1) doing interaction with NS, (2) intensive interaction with NS. On the other hand, culture assimilation occurred among NS and NNS when they (1) participated in in social activities, (2) participated in society program, and (3) antending traditional activities.

Culture assimilation of NNS toward NS indicated by following custom, tradition, and life style of NS, Indoensia and local trational food. Moreover, the most cultural immersion happened to NNS of Togean in assimilation contexts got marriage between woman NS and man NNS. Generally NNS of Togean followed NS tradtion, customs, culture, and religion.

We conclude that different language and culture background assimilation occurred when NS used a foreign language (English) to assimilate their language with NNS interaction. NS developed their language assimilation by using code switching and code mixing strategies. On the other hand, NNS also tried to acquire NS language. Culture assimilation occurred in both NS and NNS when they were doing cultural practice, cultural activities, food selection, and interpersonal contact in both NS and NNS of Togean.

3. Language and Culture Adaptation of Native Speakers and Non Native Speakers of Togean

Data transcription 1 and 2 indicated that NS adapt to NNS language. NS adapt to NNS language because of some reasons. Frst, they want to communicate with NNS. They want to have excellent service to NNS. Third, they want to have a good business. Therefore, language adaptation occurred to NS toward NNS when NNS have a short stay in Togean. However, NNS acquired NS language for making interaction. NNS also tried to acquire NS language in Indonesian and local language by asking some questions to NS of Togean.

In the process of culture and language adaptation, NS and NNS of Togean exchanged their language and culture. NS learnt NNS language, and on the other hand, NNS also learnt Indonesian and local language. However, language adaptation mostly happened to NS toward NNS language in order to guide NNS who visited Togean Islands. 
Prof. Dr. Hasanuddin et al / Acculturation of Language and Culture among Native and Non Native Speakers of Togean in Togean Island Tojo Una Una Central Sulawesi Indonesia

Inter-intra grouyp relation to NS and NNS of Togean can be seen at eating ethnic food. Based on interview and observation indicated that NNS accustomed to ethnic food. They can adapt to eat traditional food prepared by the hosts. They enjoyed to eat traditional food like eating "sagu".

Observation data indicated that language and culture adaptation of NS and NNS occurred at (1) intensive interactionwith NS and NNS, (2) followed traditional habits of the NS, (3) eat rice for meals, (4) eat traditional foods, (5) participated in social activities, and (6) attending traditional activities.

4. The Tolerance Attitude of of Native Speakers and Non Native Speakers of Togean

Tolerance is one social act that found in the research site. Society member consist of native speaker and non native speaker needed tolerance from both side for make the life safe and comfortable. There are several social aspect that get tolerance from both side. Religion is one aspect that get tolerance response from native speaker and non native speaker. Native speaker who are dominant in Moslem, automatically the rule in society that have been made is based on Moslem rule. Non native speaker that visited and stay in that place is consist of some Christian and also Atheist. Although they have different belief, but they obedient and follow the society rule that based on Moslem as society's dominant religion. For example, rule in wearing custom, don't drunk in public place, and etc. the tolerance also prevailed toward the native speaker. Native speaker didn't force the non native speaker for doing what they do in religion side. The important is non native speaker are obedient with the rule that they have been made.

The next is tradition. Tradition also gets tolerance from native speaker and non native speaker, for instance, the native speaker tradition in eating rice, cassava, and sago as their meals. Non native speaker never critic the meals that served by native speaker. Even they are really enthusiast to eat rice, and sago as their meals. Even, non native speaker ask try the traditional food of Togean island, such as Lakapeso, Ikan bakar rica, and kue sagu. Although the non native speaker interested and like eat traditional food, native speaker also served their food, such as noodle, meat stick, burger, and fried potatoe. It is one of tolerance form that showed by native speaker to non native speaker.

The other tolerance form is by living together in one place. Today, many non native speaker that have stay a long in Togean Island. They have several reason namely they love the island, they have boyfriend/girlfriend from native speaker, they interested to make resort business there, and some of them falling in love and married with native speaker. By married with native speaker or stay a long in Togean island, automatically non native speaker

5. The Sympathy Attitude of Native Speakers and Non Native Speakers of Togean

Finding in observation, field note, record, and interview showed the sympathy is one of behavior that showed by the native speaker and non native speaker in doing interaction. It presented that the native speaker and non native speaker are respect to each other. It can be seen on data that have been collected from July 2015 to September 2015. There are a lot of aspects in getting sympathy from both side. The first aspect is language. Language is one unique thing which is become specific attention between native speaker and non native speaker. In this case, there are a lot of the Togean society (Native speaker) who understand in English. The native speakers are come from different age, educational, and job. Some of them not mastery one foreign language only, but also more than one foreign language, such as English, Italy, Spanish, France, and Dutch. It also occurs toward non native speaker. There are some non native speakers who interest to learning Indnesia language. Finally they can use Indonesia in speaking to native speaker. There is also one non native speaker who stay there is speaking by using regional language, which is Togean language.

The sympathy also occurs in other aspect. It is tradition. The tradition of native speaker who have rice, cassava and sago as their meal, also followed by non native speaker who stay in Togean island. From the observation, found non native speaker eat rice routine as their meal when stay there. There is also other traditional food were be their favorite food, such as Lakapeso, Ikan bakar rica, kue Sagu, and others. Native speaker said that the non native speaker loves unique things. So, when they saw the unique food, they excited for try it. The influence of the tradition not only occurred toward the non native speaker, but also native speaker. The habitual of non native speaker step by step also influence native speaker. One of example is bir party. In the resort area, when the non native speaker did party with a lot of bir, there is also native speaker. In this case, the native speaker is someone who have job as a guide. They drink bir together. It showed that native speaker also sympathy with non native speaker tradition.

The next aspect that gets sympathy from non native speaker is culture. Togean Island is one island in Celebes, Indonesia that rich with its culture. There a lot of culture, such as custom, traditional sing, traditional dance, and traditional ceremony. Basically Native speaker have different custom rule with the non native speaker. In the early when Togean Island as a tourism destination, there are a lot of tourists (non native speaker) who visited this place by using impolite custom. The native speaker always teach them how to dress when they coming to this Island. Finally, some years there are non native speaker who wear polite custom. Beside custom, there is tradition of native speaker that attract non native speaker. It is traditional ceremony. It presented by the native people, such as Padungku, Bakedang, Kantau and others. Padungku is societies' ceremony. It is like the thanksgiving or harvest festival. It performed traditional dancing and singing which is preceded by a formal prayer or blessing. The next is bakedang. Bakedang is traditional ceremony for the young girls that get their first period. This ceremony should performances kantau. Kantau is obligated dancing that must performed in every 
Prof. Dr. Hasanuddin et al / Acculturation of Language and Culture among Native and Non Native Speakers of Togean in Togean Island Tojo Una Una Central Sulawesi Indonesia

ceremony. In every traditional ceremony, there is also some non native speaker who participated in this ceremony, although they participated as an audience only. There is also some non native speaker who have been married with native speaker, participated in traditional ceremony. When he (non native speaker) married with native speaker, he followed wedding ceremony of the native speaker tradition. He wear traditional custom and followed all of formation in traditional wedding ceremony. It is clear that the sympathy of non native people toward native people is occurred in this island.

The next aspect is rule. Every region has its own rule. It also prevails in Togean island. There are some rules made by native speaker for visitor. The kinds of rule that should be obedient by the visitors are polite custom, save a clean, don't throw away rubbish in the sea, don't walk in the reef, don't fishing in the resort area, don't use dynamite, and don't spearing fish. From the observation, almost the rules that made by the native speaker are obedient by non native speaker. There are non native speaker who never used their impolite custom in the society. They used their impolite custom when they are in resort area that far from society. Beside that, they also never rubbish the sea. Even they clean the sea if they found some rubbish in the sea.

Respect is one kind of sympathy form. From the observation, respect between native speaker and non native speaker is always happen in their daily interaction. When they met each other, they are always greeting. Non native speaker greeting native speaker by using English, then native speaker also answer the greeting by using English too. Sometimes they also used Indonesian when greet native speaker, such as selamat pagi, sampai jumpa, and others. Their enthusiastic in using and learning Indonesia language in on form of their sympathy to native speaker's language. It not only occurred toward non native speaker, but also native speaker. They also learn some foreign language. Native speaker not only come from guide, but also the seller, the children, and the other society member excited for learn and used Englsig and other foreign languages for communicate to non native speaker.

Finally, we can conclude that sympathy attitude is important unsure that should be done in interaction for make interaction running well, particularly for native speaker and non native speaker. In this research setting founded there are a lot of aspects that getting sympathy from native speaker and non native speaker. The aspect are language used, participated in traditional festival/ceremony, wear polite dress, followed the rule that made by native speaker, and many others.

\section{E. CONCLUSIONS AND RECOMMENDATIONS}

1. Conclusion

a. Different language and culture background assimilation occurred when NS used a foreign language (English) to assimilate their language with NNS interaction. NS developed their language assimilation by using code switching and code mixing strategies. On the other hand, NNS also tried to acquire NS language. Culture assimilation occurred in both NS and NNS when they were doing cultural practice, cultural activities, food selection, and interpersonal contact in both NS and NNS of Togean.

b. Language and culture adaptation of NS and NNS occurred at (1) intensive interaction with NS and NNS, (2) followed traditional habits of the NS, (3) eat rice for meals, (4) eat traditional foods, (5) participated in social activities, and (6) attending traditional activities.

c. Tolerance attitude between NS and NNS of Togean related to respects ethnics, ideology, accepted to other people, helpful, give appreciation, and permit among NS and NNS of Togean Islands. They have good tolerance attitude each other.

d. Sympathy attitude is important unsure that should be done in interaction for make interaction running well, particularly for native speaker and non native speaker. In this research setting founded there are a lot of aspects that getting sympathy from native speaker and non native speaker. The aspect are language used, participated in traditional festival/ceremony, wear polite dress, followed the rule that made by native speaker, and many others.

2. Recommendation

a. Togean Islands are hidden paradise in Tomini Bay Central Sulawesi that can become priority for visit Indonesia in the future, needed to be developed infrastructure and facility in order to develop Togean Islands for main visits Indonesia.

b. Language and culture acculturation are main aspects tourism to be a part of tourism developments that have to be paid attention of the government in Tojo Una-Una District.

\section{REFERENCES}

1. Aronoff, M. \& Kirsten F. 2001.Morphology and morphological analysis.Blackwell Publishing.Available at www.ucd.ie/artspgs/.../Aronoffmorphology.pdf.

2. Borofsky, R. 1994. Assessing cultural anthropology. United Stated of America : McGraw-Hill, Inc.

3. Bungin,B. 2012. Analisis data penelitiankualitatif. Jakarta; PT Rajagrafindo.Persada

4. Carstairs, A. \&McCharty. 2002. An introduction to englishmorphology : words and their structure. Edinburgh ; Edinburgh University Press.

5. Chaer, A. \& Leonie A. 2010.Sociolinguistikperkenalanawal. Jakarta :RinekaCipta

6. Davies, A, and Catherine. 2006. The handbook of applied linguistics. Australia :Blacwell Publishing Ltd.

7. Gleason, H.A. 1961. An introduction to descriptive linguistic. United Stated of America : Library of Congress 
Prof. Dr. Hasanuddin et al / Acculturation of Language and Culture among Native and Non Native Speakers of Togean in Togean Island Tojo Una Una Central Sulawesi Indonesia

Catalog.

8. Groves, J. 2008. Language or dialect -or topolect?A comparison of the attitudes hongkongers and mainland Chinese towards the status Cantonese.Philadelphia : University of Pennsylvania.

9. Hudson, R. A. 1980. Sociolinguistics.Melbeourne : Cambridge University Press.

10. Jenks, C. 2013. Culture ;studikebudayaan. Yogyakarta :PustakaPelajar

11. Koentjaraningrat. 2009. Pengantarilmuantropology. Jakarta :RinekaCipta

12. Krashen, S, dkk. 1982. Language two. New York : Oxford University Press

13. Kuswarno, E. 2008.Etnografikomunikasi; pengantardancontohpenelitiannya.Bandung :WidyaPadjadjaran

14. Lavenda, R.H. \& Emily A. 2003.Core concepts in cultural anthropology. United Stated of America : McGraw-Hill Companies, Inc.

15. Lewis, R . 2009. When cultures collide; leading across culture. London: WS Bookwell

16. Mathew,\& Rachel. Cultural anthropology.

17. Meurers, D. 2004. Linguistic.

18. Moleong, L. (2004). Metodologipenelitiankualitatif.Bandung; PT RemajaRosdakarya.

19. Moore, A. 2001.Phonology. Available at http://www.shunsley .eril.net/armoore/

20. Ngo, V. 2008.A Critical examination of acculturation theories. Available at http://www1.uwindsor.ca/critical socialwork/a-critical-examination-of-acculturationtheories

21. Pratiwi, P. 2011. Asimilasidanakulturasi ;sebuahtinjauankonsep. Available at http://www.google.com/url?sa=t\&rct=j\&q=\&esrc=s\&sour ce $=$ web $\& c d=2 \& c a d=r j a \& u a c t=8 \& v e d=0 C C 4 Q F j A B \& u r l$ $=$ http $\% 3 \mathrm{~A} \% 2 \mathrm{~F} \% 2 \mathrm{Fstaff}$. uny.ac.id $\% 2 \mathrm{Fsites} \% 2 \mathrm{Fdefault} \% 2$ Ffiles\%2Fpengabdian\%2Fpoerwanti-hadi-pratiwi-spdmsi\%2Fasimilasiakulturasi.pdf\&ei=LfRvU7u0MNS78gWszILYAQ\&usg= AFQjCNFucaRCCSAlgOX1E9qOEWOxiZCBbg\&bvm= bv.66330100,d.dGc

22. Smit, B\& Johanna.2006. Adaptation, adaptive capacity and vulnerability.Department of Geography, University of Guelph, Guelph, Ont., Canada N1G 2W1. Available at www.elsevier.com/locate/gloenvcha0959-3780/\$

23. Spradley, J. 2006. Metodeetnografi.Yogyakarta : Tiara Wacana

24. Strauss, A and Corbin. (2003). Dasar-
dasarpenelitiankualitatif.Yogyakarta ;PustakaPelajar

25. Sugiyono. 2013. Cara mudahmenyusunskripsi, thesis, dandisertasi. Bandung :ALFABETA,cv

26. UK Climate impact Programme. Identifying adaptation options.

27. Wijana, dkk. $2006 . \quad$ Sosiolinguistik; kajianteoridananalisis. Yogyakarta :PustakaPelajar. 